KREATIF : Jurnal Ilmiah Prodi Manajemen Universitas Pamulang, Volume 8, No. 1, Juni 2020

$\begin{array}{ll}\text { KREATIF } & \text { ISSN : 2339-0689, E-ISSN : 2406-8616 } \\ \text { Jurnal Ilmiah } & \text { J. KREATIF, Vol. 8, No.1, Juni 2020 (Halaman 47-60) } \\ \text { Prodi Manajemen Universitas Pamulang } & \text { Tersedia Online di: http://openjournal.unpam.ac.id/index.php/kreatif }\end{array}$

\title{
PENGARUH PERPUTARAN PERSEDIAAN DAN PERPUTARAN PIUTANG TERHADAP LIKUIDITAS PT ELANG MAHKOTA TEKNOLOGI TBK PERIODE TAHUN 2009-2017
}

\author{
Bulan Oktrima \\ Program Studi Manajemen Fakultas Ekonomi Universitas Pamulang \\ Email: dosen00790@ unpam.ac.id
}

\begin{abstract}
ABSTRAK
Kajian ini bertujuan untuk menentukan kesan perolehan inventori terhadap kecairan (CR) di PT Elang Mahkota Teknologi Tbk dalam tempoh 2009-2017, untuk menentukan kesan perolehan yang akan diterima oleh kecairan (CR) di PT Elang Mahkota Teknologi Tbk dalam tempoh 2009-2017 dan untuk mengetahui kesan perolehan inventori dan perolehan akaun yang boleh diterima bersama pada kecairan (CR) di PT Elang Mahkota Teknologi Tbk untuk tempoh 2009-2017. Kaedah penyelidikan yang digunakan adalah kuantitatif deskriptif.

Data yang digunakan adalah data sekunder dalam bentuk penyata kewangan PT Elang Mahkota Teknologi Tbk untuk tempoh 2009-2017. Kaedah analitik yang digunakan adalah ujian asumsi klasik, analisis regresi linear berganda, pekali korelasi, pekali penentuan, dan ujian hipotesis dengan ujian $t$ dan ujian $F$ menggunakan versi SPSS 25.0.

Keputusan menunjukkan tiada kesan ketara perolehan inventori terhadap kecairan, tidak terdapat pengaruh penting terhadap perolehan akaun yang belum diterima, dan tidak terdapat kesan yang signifikan antara perolehan inventori dan perolehan akaun yang boleh diterima bersama pada kecairan. Kadar sumbangan perolehan inventori dan perolehan hutang kepada kecairan adalah $34.4 \%$. Sementara baki $65.7 \%$ oleh pembolehubah lain (faktor atau nisbah kewangan lain) tidak diperiksa. Perolehan inventori dan akaun perolehan belum terima ke arah kecairan mempunyai hubungan yang sangat sederhana.
\end{abstract}

Kata Kunci : Perputaran Persediaan; Perputaran Piutang; dan Likuiditas.

\begin{abstract}
The purpose of this study was to determine the effect of inventory turnover on liquidity (CR) at PT Elang Mahkota Teknologi Tbk for the period 2009-2017, to determine the effect of receivable turnover on liquidity $(C R)$ at PT Elang Mahkota Teknologi Tbk for the period 2009-2017, and for find out the effect of inventory turnover and receivable turnover together on liquidity (CR) at PT Elang Mahkota Teknologi Tbk for the period 2009-2017. The research method used is descriptive quantitative.

The data used is secondary data in the form of financial statements of PT Elang Mahkota Teknologi Tbk for the period 2009-2017. The analytical method used is the classic assumption test, multiple linear regression analysis, correlation coefficient, coefficient of determination, and hypothesis testing with t test and $F$ test using SPSS version 25.0.
\end{abstract}


The results showed that there was no significant effect of inventory turnover on liquidity, there was no significant effect on accounts receivable turnover, and there was no significant influence between inventory turnover and accounts receivable turnover together towards liquidity. The level of contribution of inventory turnover and accounts receivable turnover to liquidity variables is $34.4 \%$. While the rest is $65.7 \%$ by other variables (factors or other financial ratios) that are not examined. Inventory turnover and account receivable turnover to liquidity have a very moderate relationship.

Keywords: Inventory Turnover; Receivables Turnover; and Liquidity.

\section{PENDAHULUAN}

\section{A. Latar Belakang}

Pada perkemmbangan zaaman yaang semaakin pesat, membuat perkembangan perekonomian juga menjadi sangat pesat. Dengan kondisi seperti ini dikehendaki dapat menghasilkan keputusan yang tepat untuk pencapaian matlamat korporat pada masa akan datang. Untuk membuat keputusan, pengurus syarikat memerlukan maklumat, terutama maklumat mengenai apa yang mungkin berlaku pada masa akan datang. Kenyataan kewangan adalah salah satu sumber maklumat yang boleh digunakan untuk membantu dalam menilai prestasi syarikat.

Satu indikator yang boleh digunakan untuk menilai sebuah syarikat adalah nisbah kecairan. Menurut Kasmir (2015: 110) Nisbah kecairan adalah nisbah yang menggambarkan keupayaan syarikat untuk memenuhi kewajiban jangka pendek.

Salah satu unsur terbesar aset semasa adalah inventori. Sekiranya syarikat boleh menguruskan inventori dengan baik, maka syarikat itu boleh menukar inventori dengan segera melalui jualan yang akan menghasilkan penghutang dan akan menjadi wang tunai pada masa pengebilan. Menurut Kasmir (2015: 180) perolehan inventori ialah nisbah yang diguunakan unntuk menguukur beerapa ka li dana yang dilaburkan dalam inventori ini berputar dalam satu tempoh.

Aktiva lancar laain yang likuid addalah piutang. Piutang yaang ditimbulkan karena penjualan kredit akan menentukan besarnya tingkat perolehan akaun belum terima. Menurut Kasmir (2015: 176) Perolehan penerimaan adalah nisbah yang diguunakan unntuk menngukur berrapa lamma penghutang dalam tempoh atau berapa kali dana yang dilaburkan dalam penghitungan ini berputar dalam satu tempoh.

Berikut data perrputaran persediaan (inventory turnover), perputaran piutang (receivable turnover) dan likuiditas (CR) PT Elang Mahkota Teknologi Tbk periode 2009-2017.

Tabel 1.1

Perolehan Inventori, Perolehan Penghutang, Kecairan (CR) PT . Elang Mahkota Teknologi Tb k

Periode 2009-2017

\begin{tabular}{|c|c|c|c|}
\hline Tahun & $\begin{array}{c}\text { Perputaran Persediaan } \\
\text { (Decimal) }\end{array}$ & $\begin{array}{c}\text { Perputaran Piutang } \\
\text { (Decimal) }\end{array}$ & $\begin{array}{c}\text { Current Ratio } \\
\text { (Decimal) }\end{array}$ \\
\hline 2009 & 6.45 & 4.02 & 3.43 \\
\hline 2010 & 7.73 & 5.53 & 4.42 \\
\hline 2011 & 7.74 & 5.02 & 1.42 \\
\hline
\end{tabular}




\begin{tabular}{|l|l|l|l|}
2012 & 7.35 & 4.55 & 5.42 \\
\hline 2013 & 7.28 & 5.06 & 4.31 \\
\hline 2014 & 6.00 & 4.25 & 7.80 \\
\hline 2015 & 5.54 & 4.21 & 7.93 \\
\hline 2016 & 5.13 & 4.64 & 5.08 \\
\hline 2017 & 4.64 & 4.43 & 5.64 \\
\hline
\end{tabular}

Sumber: Data diolah (2018)

\section{Perputaran Persediaan, Perputaran Piutang, Likuiditas (CR)}

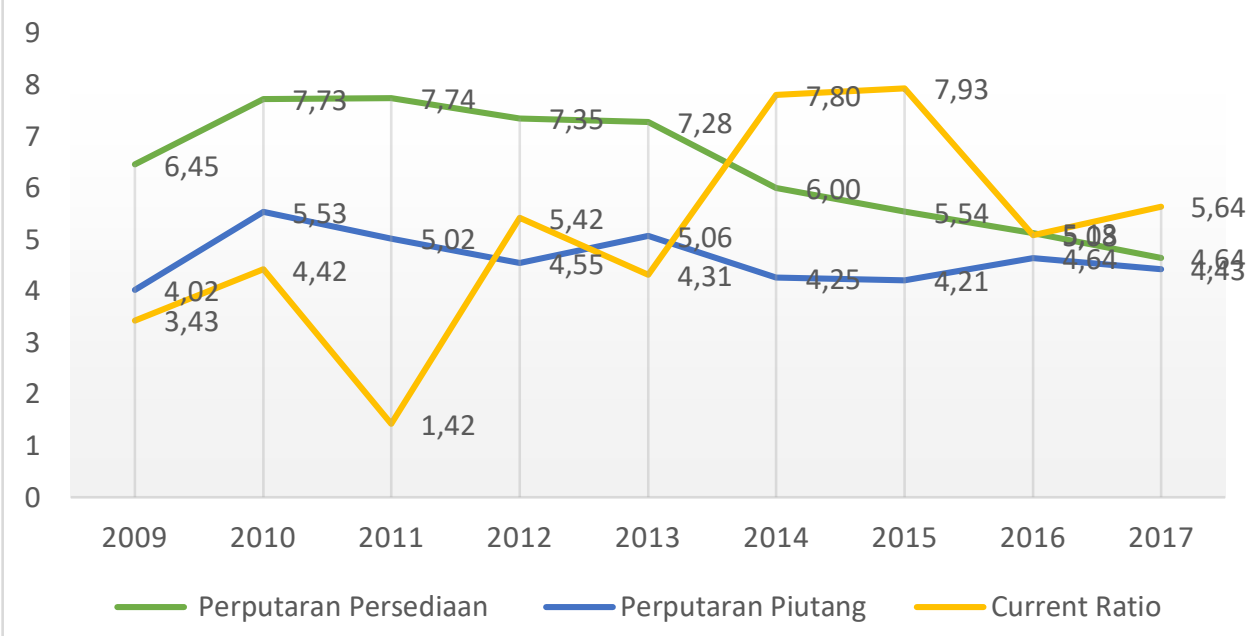

Sumber: Data diolah (2018)

\section{Grafik 1.1 \\ Perputaran Persediaan, Perputaran Piutang, Likuiditas (CR) PT Elang Mahkota Teknologi Tbk Periode 2009-2017}

Beerdasarkan data paada Taabel 1.1 dan G rafik 1.1 menuunjukkan baahwa perputaran persediaan pada PT Elang Mahkota Teknologi Tbk pada tahun 20092017 mengalami naik turun atau fluktuasi. Penurunan yang signifikan terjadi dari tahun 2013 sampai tahun 2017 dan yang terendah terjadi pada tahun 2017 sebesar 4.64 kali. Dan perputaran piutang pada PT Elang Mahkota Teknologi dari tahun 2009 sampai 2017 mengalami fluktuasi. Tingkat perputaran piutang terbesar yaitu pada tahun 2010 sebesar 5.53 kali dan perputaran terendah terjadi pada tahun 2009 sebesar 4.02 kali. Dan likuiditas PT Elang Mahkota Teknologi yang diproksikan oleh rasio lancar (current ratio) dari tahun 2009 sampai 2017 juga tidak stabil atau mengalami fluktuasi. Likuiditas terbesar yaitu pada tahun 2015 sebesar 7.93 kali dan mengalami penurunan pada tahun 2016 sebesar 5.08 kali dan mengalami kenaikan lagi pada tahun 2017 sebesar 5.64 kali dan terendah pada tahun 2011 sebesar 1.42 kali.

Dan berdasarkan uraian di atas, penulis berminat untuk menjalankan penyelidikan mengenai sama ada perolehan dan perolehan boleh diterima bagi mempengaruhi kecairan syarikat dengan tajuk penyelidikan "Pengaruh 


\section{Perputaran Persediaan dan Perputaran Piutang Terhadap Likuiditas PT Elang Mahkota Teknologi Tbk Periode 2009-2017”.}

\section{B. Perumusan Masalah}

BerdaAsarkan laatar beelakang yaang diterangkan dii attas, penulis mencipta masalah seperti berikut:

1. Apakah terdapat peengaruh perputaran persediaan terrhadap likuiditas (CR) pada PT Elang Mahkota Teknologi T bk periode tahun 2009-2017?

2. Appakah terdapat pengaruh perolehan akaun pada kecairan (CR) di PT Elang Mahkota Teknologi Tbk untuk tempoh 2009-2017?

3. Apakah terdapat pengaruh perolehan inventori dan akaun perolehan belum terima bersama terhadap kecairan (CR) di PT Elang Mahkota Teknologi Tbk untuk tempoh 2009-2017?

\section{Pembatasan Masalah}

Dengan batasan penyelidik dan lebih mudah difahami dan difahami, dalam kajian ini penulis memberikan batasan-batasan di bawah kajian, iaitu mengenai perolehan inventori, perolehan akaun penerimaan dan pengaruhnya terhadap likuiditas pada PT Elang Mahkota Teknologi Tbk dengan data yang di ambil berupa laporan keuangan PT Elang Mahkota Teknologi Tbk periode 2009 sampai dengan 2017.

\section{Tujuan Penelitian}

Merujuk kepada penggubalan masalah ini, kajian ini bertujuan untuk mencari bukti empirikal mengenai perkara-perkara berikut:

1. Untuk menentukan kesan perolehan inventori terhadap kecairan (CR) di PT Elang Mahkota Teknologi Tbk dalam tempoh 2009-2017.

2. Untuk menentukan kesan perolehan akaun pada kecairan (CR) di PT Elang Mahkota Teknologi Tbk untuk tempoh 2009-2017.

3. Untuk menentukan kesan perolehan inventori dan perolehan akaun yang boleh diterima bersama pada kecairan (CR) di PT Elang Mahkota Teknologi Tbk untuk tempoh 2009-2017.

\section{E. Manfaat Penelitian}

Hasil kajian ini dijangka memberi manfaat kepada semua orang, termasuk:

1. Manfaat Teoritis

a. Untuk mengembangkan pengetahuan yang dimiliki dan menambah wawasan yang berkaitan dengan sains dan mata pelajaran yang diajar

2. Mannfaat Keilmuan

a. bagai pelengkap kepada perbendaharaan perpustakaan dan juga boleh dipertimbangkan untuk rakan-rakan pensyarah dan pelajar yang akan menjalankan penyelidikan atau masalah yang sama.

b. Hasil kajian ini dijangka akan digunakan untuk memperoleh pandangan mengenai pengetahuan tentang analisis perolehan inventori dan perolehan akaun yang akan diterima ke arah tahap kecairan. 


\section{TINJAUAN PUSTAKA}

\section{A. Perputaran Persediaan}

Perolehan inventori adalah satu jenis nisbah aktiviti. Inventori diperlukan untuk mengekalkan kelancaran operasi syarikat dalam memenuhi permintaan pengguna setiap masa. Kerana inventori adalah elemen terbesar dalam aset dan berkaitan langsung dengan aktiviti utama syarikat, terutamanya dalam syarikat industri jika tidak ada satu jenis inventori yang tersedia, proses pengeluaran akan terganggu.

Menurut Kasmir (2015: 180) perolehan inventori ialah nisbah yang digunakan untuk mengukur bilangan kali dana itu dilaburkan dalam inventori ini berputar dalam satu tempoh.

Perolehan inventori boleh dirumuskan seperti berikut:

$$
\text { Inventory Turnover }=\frac{\text { Harga Pokok Penjualan }}{\text { Rata }- \text { rata Persediaan }}
$$

\section{B. Perputaran Piutang}

Perolehan penghutang dimasukkan dalam satu jenis nisbah aktiviti. Penghutang merupakan elemen modal kerja yang sentiasa berada dalam keadaan berputar. Tempoh perolehan ini akan bermula pada masa tunai dikeluarkan untuk mendapatkan inventori dan inventori tersebut dijual secara kredit supaya ia akan menyebabkan penghutang di mana penghutang akan diubah kembali kepada tunai pada masa pembayaran penghutang ini oleh pelanggan mereka.

Menurut Kasmir (2015: 176), jumlah perolehan boleh terima adalah nisbah yang digunakan untuk mengukur berapa lama penghutang dalam tempoh atau berapa kali dana yang dilaburkan dalam penghitungan ini berputar dalam satu tempoh. Nisbah yang lebih tinggi menunjukkan bahawa modal kerja yang dilaburkan dalam penghutang adalah lebih rendah (berbanding nisbah tahun sebelumnya) dan sudah tentu keadaan ini untuk syarikat lebih baik.

Menurut Kasmir (2015: 176) formula untuk mencari perolehan boleh terima adalah seperti berikut:

$$
\text { Receivable Turnover }=\frac{\text { Penjualan Kredit }}{\text { Rata }- \text { rata Piutang }}
$$

Atau:

$$
\text { Receivable Turnover }=\frac{\text { Penjualan Kredit }}{\text { Piutang }}
$$

\section{Likuiditas}

Menurut Kasmir (2015: 110) nisbah kecairan adalah nisbah yang menggambarkan kemampuan syarikat untuk memenuhi kewajiban jangka pendek. Satu lagi fungsi nisbah kecairan adalah untuk menunjukkan atau mengukur keupayaan syarikat untuk memenuhi kewajipan yang sepatutnya, kedua-dua obligasi kepada pihak luar dan dalam syarikat. Atau dengan kata lain, nisbah kecairan adalah yang menunjukkan keupayaan syarikat untuk 
membayar hutang jangka pendek (liabiliti) yang sepatutnya, atau nisbah untuk menentukan keupayaan syarikat untuk membiayai dan memenuhi obligasi (hutang) apabila dibilkan.

Secara umum, tujuan utama nisbah kecairan digunakan untuk menilai kemampuan syarikat untuk memenuhi kewajibannya. Walau bagaimanapun, selain daripada nisbah kecairan dapat dilihat hal-hal lain yang lebih spesifik yang juga masih berkaitan dengan kemampuan perusahaan untuk memenuhi kewajibannya. Ia semua bergantung pada jenis nisbah kecairan yang digunakan. Dalam amalan, untuk mengukur nisbah kewangan sepenuhnya, boleh menggunakan jenis nisbah kecairan yang ada.

1. Rasio Lancar (Current Ratio)

Menurut Kasmir (2015: 134) nisbah saat ini adalah nisbah untuk mengukur keupayaan syarikat untuk membayar liabiliti jangka pendek atau hutang yang perlu dibayar segera apabila ditagih secara keseluruhan. Menurut Kasmir (2015: 135) formula untuk mencari nisbah semasa boleh digunakan seperti berikut:

$$
\text { Current Ratio }=\frac{\text { Aktiva Lancar }(\text { Current Assets })}{\text { Utang Lancar }(\text { Current Liabilities })}
$$

2. Rasio Cepat (Quick Ratio)

Menurut nisbah Kasmir (2015: 136) atau nisbah yang sangat lancar atau nisbah uji asid adalah nisbah yang menunjukkan kemampuan syarikat untuk memenuhi atau membayar hutang atau hutang semasa (hutang jangka pendek) dengan aset semasa tanpa memperhatikan nilai inventori . Menurut Kasmir (2015: 137) formula untuk mencari nisbah cepat (nisbah cepat) dapat digunakan sebagai berikut:

$$
\text { Quick Ratio }(\text { Acid Test Ratio })=\frac{\text { Current Assets }- \text { Inventory }}{\text { Current Liabilities }}
$$

atau

$$
\text { Quick Ratio }(\text { Acid Test Ratio })=\frac{\text { Kas }+ \text { Bank }+ \text { Efek }+ \text { Piutang }}{\text { Current Liabilities }}
$$

3. Rasio Kas (Cash Ratio)

Menurut Kasmir (2015: 138) nisbah tunai adalah alat yang digunakan untuk mengukur jumlah tunai yang tersedia untuk membayar hutang. Menurut Kasmir (2015: 139) formula untuk mencari nisbah tunai boleh digunakan seperti berikut:

$$
\text { Cash Ratio }=\frac{\text { Cash or Cash Equivalent }}{\text { Current Liabilities }}
$$

atau

$$
\text { Cash Ratio }=\frac{\text { Kas }+ \text { Bank }}{\text { Current Liabilities }}
$$




\section{Kerangka Pemikiran}

Kerangka pemikiran yang dikembangkan untuk penelitian ini adalah:

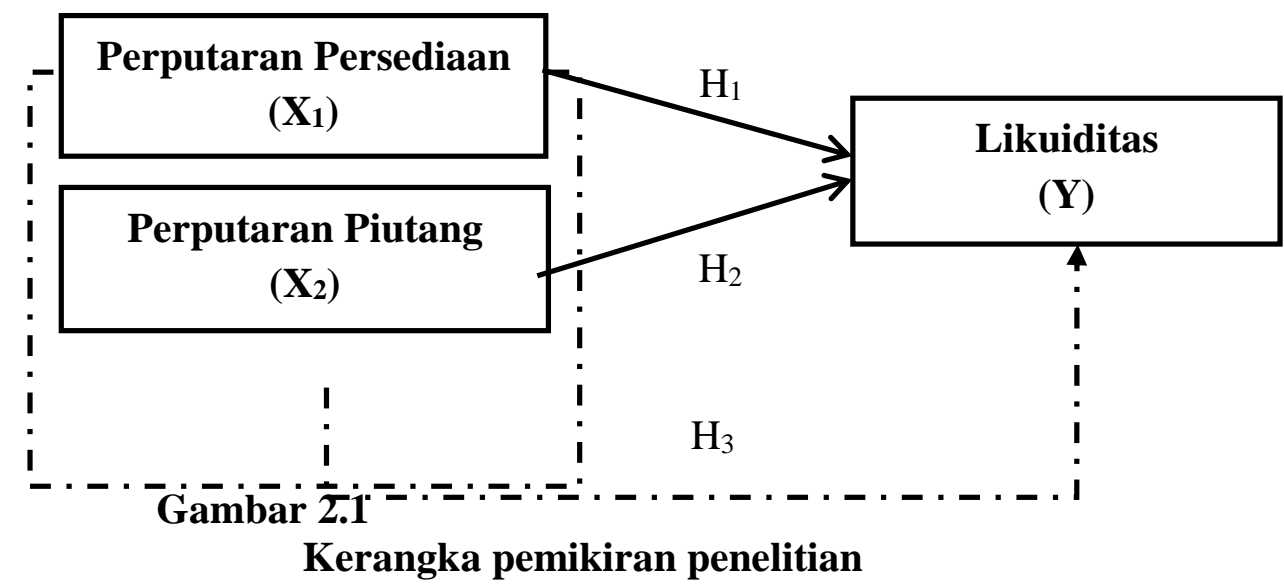

\section{E. Hipotesis Penelitian}

Hipotesis yang dicadangkan oleh pengarang adalah seperti berikut:

Ha1 $=0$ : Diduga terdapat pengaruh antara perputaran persediaan terhadap likuiditas pada PT Elang Mahkota Teknologi Tbk.

$\mathrm{Ha} 2=0$ : Diduga terdapat pengaruh antara perputaran piutang terhadap likuiditas pada PT Elang Mahkota Teknologi Tbk.

$\mathrm{Ha3}=0: \quad$ Diduga terdapat pengaruh antara perputaran persediaan dan perputaran piutang secara bersama-sama terhadap likuiditas pada PT Elang Mahkota Teknologi Tbk.

\section{METODOLOGI PENELITIAN}

A. Tempat dan Waktu Penelitian

Kajian ini dijalankan di PT Elang Mahkota Teknologi Tbk yang terletak di Menara SCTV, Tingkat 18, Senayan City Jl. Asia Afrika Lot 19, Jakarta 10270, Indonesia. Kajian ini dijalankan selama 6 bulan dari Disember 2018 hingga Jun 2019

\section{B. Metode Penelitian}

Penyelidikan yang dijalankan dalam aktiviti ini adalah deskriptif kuantitatif dengan tujuan penyelidikan deskriptif adalah untuk mendapatkan gambaran keseluruhan syarat-syarat pembolehubah yang dikaji manakala penyelidikan kuantitatif ditafsirkan sebagai kaedah penyelidikan berdasarkan falsafah positivisme, digunakan untuk mengkaji populasi atau sampel tertentu, pengumpulan data menggunakan instrumen penyelidikan, analisis data adalah kuantitatif atau statistik untuk menguji hipotesis yang telah ditetapkan..

\section{Populasi dan Sampel}

\section{Populasi}

Menurut Sugiyono (2017: 80) populasi adalah area generalisasi yang terdiri dari: objek / subjek yang memiliki sifat dan karakteristik tertentu 
yang ditentukan oleh para penyelidik untuk belajar dan kemudian membuat kesimpulan. Populasi dalam kajian ini adalah keseluruhan laporan kewangan PT Elang Mahkota Teknologi Tbk.

\section{Sampel}

Menurut Sugiyono (2017: 81) sampel itu adalah bagian dari jumlah dan karakteristik yang dimiliki oleh penduduk. Sampel yang digunakan dalam kajian ini adalah kunci kira-kira dan penyata pendapatan PT Elang Mahkota Teknologi Tbk dari tahun 2009 hingga 2017.

\section{Metode Analisis Data}

Metode yang digunakan dalam penelitian ini adalah:

\section{Statistik Deskriptif}

Menurut Kasmir (2017: 147) statistik deskriptif adalah statistik yang digunakan untuk menganalisis data dengan menerangkan atau menerangkan data yang dikumpulkan kerana ia tidak bermaksud membuat kesimpulan yang umum atau umum.

\section{Uji Asumsi Klasik}

\section{a. Uji Normalitas}

Ujian normal adalah ujian untuk mengukur sama ada data yang diperolehi mempunyai taburan normal supaya dapat digunakan dalam statistik parametrik. Dalam kajian ini, ujian normal menggunakan ujian P Plot biasa. Menurut Imam Ghozali (2013: 163) pengesanan normality adalah berdasarkan prinsip-prinsip berikut:

1) Jika data merebak di sekitar garis pepenjuru dan mengikuti arah garis pepenjuru, model regresi memenuhi asumsi normal

2) Jika data menyebar jauh dari garis pepenjuru atau tidak mengikuti arah garis pepenjuru, maka model regresi tidak memenuhi asumsi-asumsi klasik.

\section{b. Uji Heteroskedastisitas}

Ujian heteroskedastisiti digunakan untuk menentukan sama ada terdapat sisihan dari anggapan klasik heteroscedasticity, iaitu, varians dan ketidaksamaan residu untuk semua pemerhatian dalam model regresi. Dalam kajian ini, satu cara untuk mengesan heteroscedasticity adalah dengan melihat grafik scatterplot dengan merancang nilai ZPRED (nilai yang diramalkan) dengan SRESID (nilai sisa). Model yang baik diperolehi sekiranya mata peruntukkan tersebar secara rawak dan tidak ada corak khusus pada graf, seperti berkumpul di tengah, menyempit kemudian pelebaran atau sebaliknya pelebaran kemudian menyempitkan, dapat disimpulkan bahwa tidak ada masalah heteroskedastisitas.

\section{c. Uji Multikolinieritas}

Ujian multicollineariti bertujuan untuk menguji sama ada model regresi menemui korelasi antara pembolehubah bebas (bebas). Alat statistik yang sering digunakan untuk menguji gangguan multicollineariti adalah untuk melihat nilai toleransi dan VIF (Variance Inflation Factor). Nilai disyorkan untuk menunjukkan ketidakhadiran masalah multicollinearity adalah nilai Toleransi mestilah $>0.10$ dan nilai VIF $<10$. 


\section{Regresi Linear Berganda}

Analisis regresi linier berganda digunakan untuk menentukan sama ada terdapat pengaruh pembolehubah bebas pada pembolehubah bergantung. Persamaan regresi linear berganda boleh dirumuskan seperti berikut:

$$
\mathrm{Y}=\mathrm{a}+\mathrm{b}_{1} \mathrm{X}_{1}+\mathrm{b}_{2} \mathrm{X}_{2}
$$

Keterangan:

$$
\begin{array}{ll}
\mathrm{Y} & : \text { Variabel dependen } \\
\mathrm{X}_{1} \mathrm{X}_{2} & \text { : Variabel independen } \\
\mathrm{a} & \text { : Nilai konstanta } \\
\mathrm{b}_{1} \mathrm{~b}_{2} & \text { : Nilai koefisien regresi }
\end{array}
$$

\section{Koefisien Korelasi}

Analisis koefisien korelasi digunakan untuk menentukan kekuatan hubungan antara kedua-dua korelasi pembolehubah dan saiz yang digunakan untuk menentukan tahap atau kekuatan korelasi. Koefisien korelasi berganda boleh dikira menggunakan formula:

$$
r=\frac{n \sum X Y-\sum X \sum Y}{\sqrt{\left(n \sum X^{2}-\left(\sum X\right)^{2}\right)\left(\left(n \sum Y^{2}-\left(\sum Y\right)^{2}\right)\right.}}
$$

Keterangan:

$\mathrm{r} \quad$ :Koefisien korelasi

n : Jumlah tahun

$\mathrm{X}$ : Variabel bebas

$\mathrm{Y}$ : Variabel terikat

Untuk memberikan koefisien korelasinya, maka penulis menggunakan pedoman ini:

\begin{tabular}{|c|c|}
\hline Interval Koefisien & Tingkat Hubungan \\
\hline $0,00-0.19$ & Sangat Rendah \\
\hline $0,20-0,399$ & Rendah \\
\hline $0,40-0,599$ & Sedang \\
\hline $0,60-0,799$ & Kuat \\
\hline $0,800-1,000$ & Sangat Kuat \\
\hline
\end{tabular}

Sumber: Sugiyono (2017:184)

\section{Koeefisien Deteerminasi}

Menurut Imam Ghozali (2013: 97) pekali penentuan $\left(\mathrm{R}^{2}\right)$ pada asasnya mengukur sejauh mana keupayaan model untuk menjelaskan variasi pembolehubah bebas. Koefisien penentuan (Kd) dikira oleh formula berikut:

$$
\mathrm{Kd}=\mathrm{r}^{2} \times 100 \%
$$

Keterangan:

Kd : Koefisien determinasi

$\mathrm{r}^{2} \quad$ : Koefisien kuadrat korelasi ganda

\section{Uji Hipotesis}

\section{a. Uji t}

Menurut Imam Ghozali (2013: 98) statistik ujian t pada dasarnya menunjukkan sejauh mana pengaruh satu pemboleh ubah bebas secara individu dalam menerangkan pembolehubah yang bergantung. 


\section{b. Uji F}

Menurut Imam Ghozali (2013: 98) Ujian statistik pada dasarnya menunjukkan sama ada semua pembolehubah bebas yang termasuk dalam model mempunyai pengaruh bersama pada pembolehubah bergantung.

\section{HASIL DAN PEMBAHASAN}

\section{Statistik Deskriptif}

Tabel 4.4

Analisis Deskriptif

Descriptive Statistics

\begin{tabular}{lc|c|c} 
& Mean & Std. Deviation & $\mathrm{N}$ \\
\hline Likuiditas & 5.0500 & 2.03373 & 9 \\
\hline Perputaran Persediaan & 6.4289 & 1.16439 & 9 \\
\hline Perputaran Piutang & 4.6344 & .48557 & 9 \\
\hline
\end{tabular}

Sumber: Output SPSS Versi 25

Berdasarkan jadual 4.4 di atas diketahui bahawa bilangan sampel yang digunakan adalah 9 sampel, iaitu penyata kewangan PT Elang Mahkota Teknologi dari 2009 hingga 2017. Telah diketahui bahawa perubahan purata dalam kecairan adalah 5.0500 dengan sisihan piawai 2.03373. Perolehan inventori mempunyai purata 6.4289 dengan sisihan piawai 1.16439 . Dan perolehan akaun belum terima mempunyai nilai purata 4.6344 dengan sisihan piawai 0.48557 .

\section{Uji Asumsi Klasik}

\section{a. Uji Normalitas}

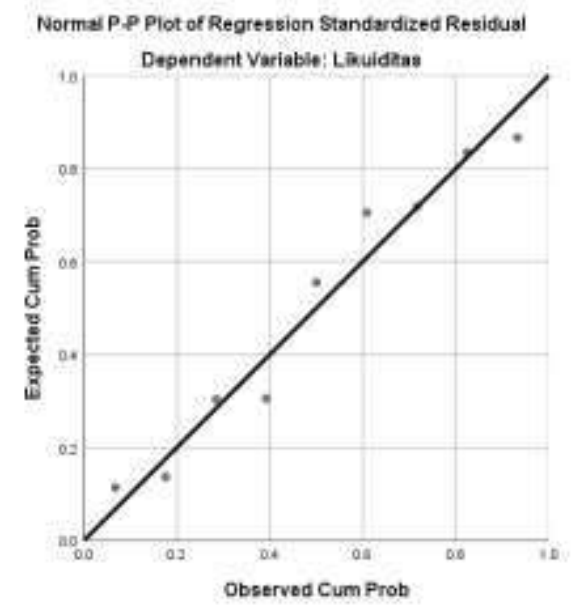

Sumber: Output SPSS versi 25.0

\section{Gambar 4.2}

\section{Hasil Uji Normalitas}

Dari grafik biasa plot kebarangkalian di atas dapat dilihat bahawa data merebak di sekitar garis pepenjuru dan mengikuti garis pepenjuru, dapat disimpulkan bahwa data yang digunakan sebagai bahan penyiasatan memiliki data distribusi normal atau memenuhi asumsi klasik normal. 
b. Uji Heteroskedastisitas

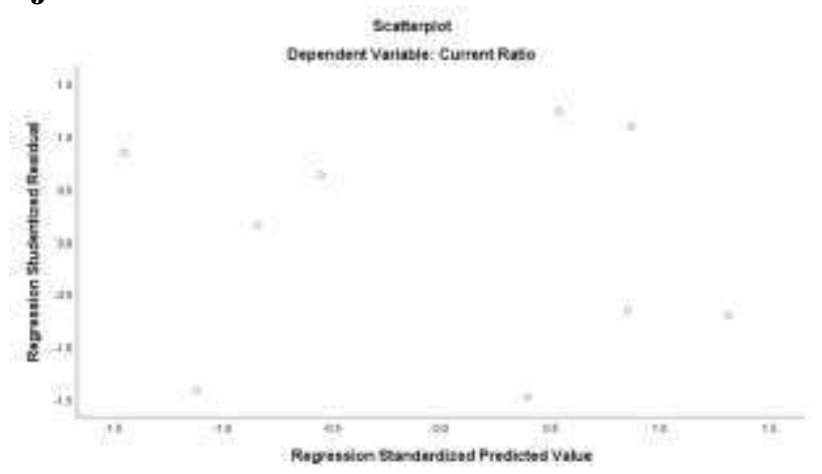

Sumber: Output SPSS Versi 25.0

Gambar 4.3

Hasil Uji Heteroskedastisitas

Dari graf scatterplot di atas dapat dilihat bahawa titik-titik yang terbentuk bertaburan secara rawak dengan corak yang tidak jelas dan tidak berkumpul di satu tempat. Ini menunjukkan bahawa data penyelidikan tidak berlaku heteroscedasticity atau data memenuhi asumsi klasik heteroscedasticity.

\section{c. Uji Multikolinearitas}

\section{Tabel 4.5}

\section{Hasil Uji Multikolinearitas}

\begin{tabular}{|c|c|c|c|c|c|c|c|c|}
\hline \multicolumn{9}{|c|}{ Coefficients ${ }^{a}$} \\
\hline \multirow{2}{*}{\multicolumn{2}{|c|}{ Model }} & \multicolumn{2}{|c|}{$\begin{array}{l}\text { Unstandardized } \\
\text { Coefficients }\end{array}$} & \multirow{2}{*}{$\begin{array}{l}\text { Standardized } \\
\text { Coefficients } \\
\text { Beta }\end{array}$} & \multirow[b]{2}{*}{$\mathrm{T}$} & \multirow[b]{2}{*}{ Sig. } & \multirow{2}{*}{$\begin{array}{l}\text { Collinearit } \\
\text { Tolerance }\end{array}$} & \multirow{2}{*}{$\begin{array}{l}\text { Statistics } \\
\text { VIF }\end{array}$} \\
\hline & & $\mathrm{B}$ & Std. Error & & & & & \\
\hline$\overline{1}$ & (Constant) & 13.741 & 6.469 & & 2.124 & .078 & & \\
\hline & Perputaran Persediaan & -.783 & .743 & -.448 & -1.053 & .333 & .605 & 1.653 \\
\hline & Perputaran Piutang & -.789 & 1.782 & -.188 & -.443 & .673 & .605 & 1.653 \\
\hline
\end{tabular}

a. Dependent Variable: Likuiditas

Sumber: Output SPSS versi 25.0

Berdasarkan keputusan yang didapati dalam jadual 4.5 di atas, diperoleh nilai toleransi untuk semua pembolehubah $>0.10$, iaitu perolehan inventori 0,605 dan perolehan akaun 0.605. Nilai VIF untuk semua pembolehubah $<10$ VIF inventori perolehan 1,653 dan VIF perolehan penghutang 1,653 , tidak ada nilai toleransi $<0.10$ dan nilai VIF> 10, dapat disimpulkan bahawa data di atas memenuhi ujian anggapan multicollinear klasik.

\section{Regresi Linear Berganda}

\section{Tabel 4.6}

\section{Hasil Analisa Regresi Linear Berganda}

Coefficients ${ }^{\mathrm{a}}$

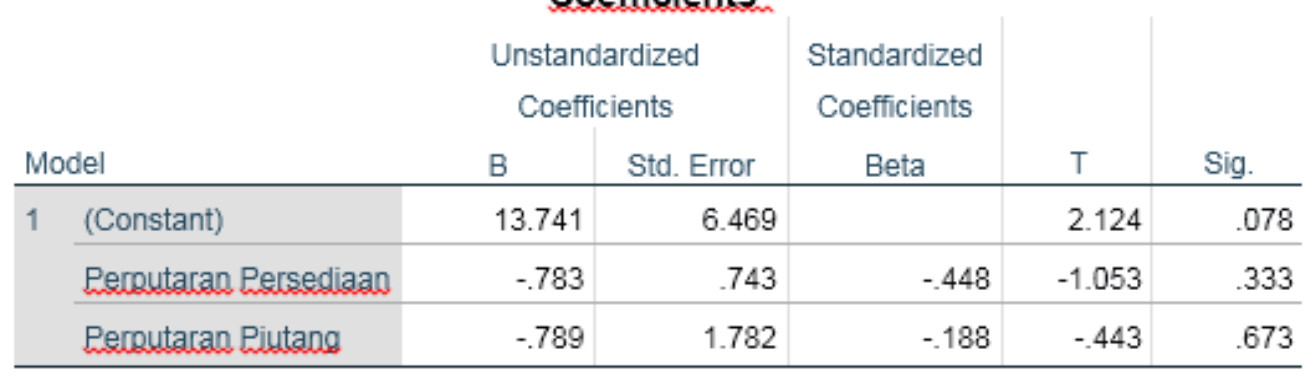

a. Dependent Variable: Current Ratio 


$$
\begin{gathered}
\mathrm{CR}=13.741-0.783 \text { Perputaran Persediaan } \\
-0.789 \text { Perputaran Piutang }
\end{gathered}
$$

Ini bermakna bahawa perolehan inventori dan perolehan akaun belum terima mempunyai hubungan negatif ke arah kecairan (nisbah semasa).

\section{Koefisien Korelasi}

Tabel 4.7

Hasil Analisis Koefisien Korelasi

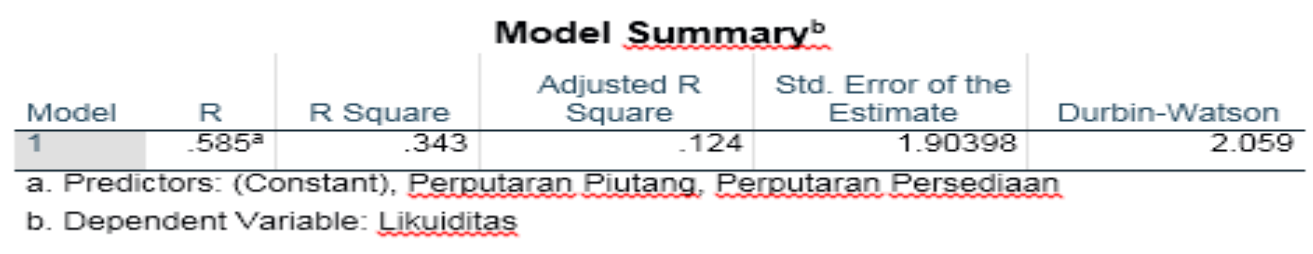

Sumber: Output SPSS versi 25.0

Dari jadual 4.7 di atas, nilai R 0.585 diperolehi, ini menunjukkan bahawa terdapat hubungan yang sederhana antara perolehan inventori dan perolehan akaun yang boleh diterima ke arah kecairan.

5. Koefisien Determinasi

Tabel 4.8

\begin{tabular}{|c|c|c|c|c|c|}
\hline \multicolumn{6}{|c|}{ Model Summaryb } \\
\hline Model & $\mathrm{R}$ & $\mathrm{R}$ Square & $\begin{array}{l}\text { Adjusted R } \\
\text { Square }\end{array}$ & $\begin{array}{l}\text { Std. Error of the } \\
\text { Estimate }\end{array}$ & Durbin-Watson \\
\hline 1 & $.585^{a}$ & .343 & .124 & 1.90398 & 2.059 \\
\hline
\end{tabular}

Hasil Analisis Koefisien Determinasi

Sumber: Output SPSS Versi 25.0

Daripada jadual 4.8 di atas diketahui bahawa pekali penentuan ( $R$ persegi) 0.343 atau bersamaan dengan $34.3 \%$. Ini menunjukkan bahawa perolehan perolehan inventori dan perolehan akaun yang boleh diterima kepada kecairan adalah $34.4 \%$. Sementara baki $65.7 \%$ oleh pembolehubah lain (faktor atau nisbah kewangan lain) tidak diperiksa.

6. Uji Hipotesis
a. Uji t

Tabel 4.9

Hasil Regresi Uji t

$\Psi$

Coefficients ${ }^{\mathrm{a}}$

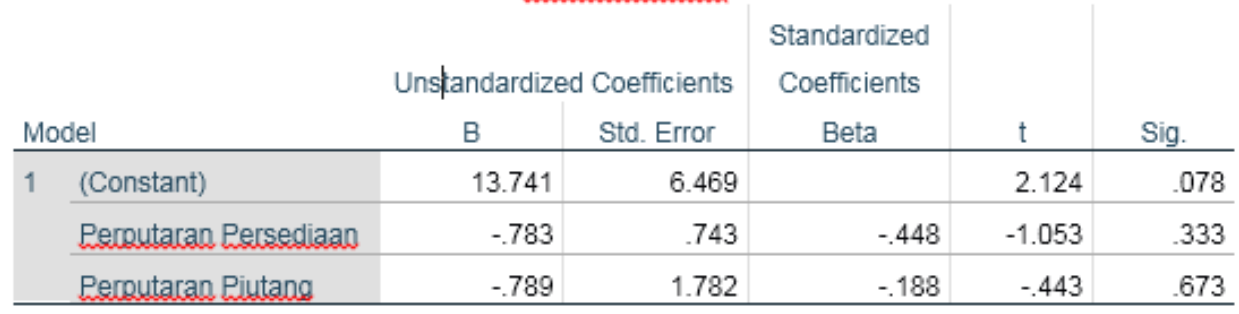

a. Dependent Variable: Current Ratio

0.333 adalah lebih besar daripada tahap yang ditentukan $\alpha=$

0.05, Ha1 ditolak dan Ho1 diterima. Ini bermakna ia dapat 
disimpulkan bahawa tiada kesan ketara perolehan inventori terhadap kecairan PT Elang Mahkota Teknologi Tbk dalam tempoh 2009-2017.

2) Pengaruh Perputaran Piutang (X2) terhadap Likuiditas (Y)

Berdasarkan keputusan ujian t pada jadual 4.8 titung untuk perolehan akaun penerimaan -0.443 dan ttable ialah 2.44691 . Jadi kerana nilai tcount <ttable ialah $-0.443<2.44691$ dan tahap signifikan 0.673 lebih besar daripada tahap yang dinyatakan $\alpha=$ 0.05 , Ha2 ditolak dan $\mathrm{Ho} 2$ diterima. Ini bermakna dapat disimpulkan bahawa tidak terdapat pengaruh penting dari jumlah perolehan yang dapat diterima pada kecairan PT Elang Mahkota b. Uji F Teknologi Tbk untuk tempoh 2009-2017.

\begin{tabular}{|c|c|c|c|c|c|c|}
\hline & & $\begin{array}{r}\text { Tabel } \\
\text { Hasil Reg }\end{array}$ & 10 & & & \\
\hline & & & OYA & & & \\
\hline Mode & & $\begin{array}{l}\text { Sum of } \\
\text { Squares }\end{array}$ & & Mean Square & $\mathrm{F}$ & Sig. \\
\hline 1 & Regression & 11.338 & 2 & 5.669 & 1.564 & $.284^{\circ}$ \\
\hline & Residual & 21.751 & 6 & 3.625 & & \\
\hline & Total & 33.089 & 8 & & & \\
\hline $\begin{array}{l}\text { a. Der } \\
\text { b. Pre }\end{array}$ & $\begin{array}{l}\text { pendent Variab } \\
\text { edictors: (Const }\end{array}$ & $\begin{array}{l}\text { rent Ratio } \\
\text { Eroutacan Riuta }\end{array}$ & Rerouts & Lan Persediaan. & & \\
\hline $\begin{array}{l}\text { ialah } \\
\text { denga } \\
\text { penga } \\
\text { itu, ke } \\
0.284 \\
\text { Ha3 c } \\
\text { antara } \\
\text { bersan } \\
\text { tempo }\end{array}$ & $\begin{array}{l}\text { 1.564. Dan } \\
\text { an kepentin } \\
\text { angka df } 2 \mathrm{~d} \\
\text { erana Fcoun } \\
\text { adalah lebi } \\
\text { ditolak dan } \\
\text { a perolehan } \\
\text { ma pada ke } \\
\text { oh 2009-201 }\end{array}$ & $\begin{array}{l}\text { ksibel boleh } \\
0.05 / 2= \\
\text { nyebut df } 6 \mathrm{~s} \\
\text { able adalah } \\
\text { ar daripada } \\
\text { diterima. I } \\
\text { tori dan pero } \\
\text { n PT Elang }\end{array}$ & $\begin{array}{l}\text { lidapati } \\
0.025 \\
\text { paya Fl } \\
564<5 . \\
\text { hap ya } \\
\text { berma } \\
\text { han ak } \\
\text { Mahkot: }\end{array}$ & $\begin{array}{l}\text { dalam jadu } \\
\text { (ujian 2-eko } \\
\text { eksibel ialah } \\
14 \text { dan tahap } \\
\text { ng ditentukan } \\
\text { kna tiada ke } \\
\text { aun yang bole } \\
\text { Teknologi }\end{array}$ & $\begin{array}{l}\text { statist } \\
\text { deng } \\
14 . \mathrm{Ol} \\
\text { gnifik } \\
=0.0 \\
\text { n keta } \\
\text { diterin } \\
\text { k unt }\end{array}$ & \\
\hline
\end{tabular}

\section{KESIMPULAN DAN SARAN}

\section{A. Kesimpulan}

1. Tiada kesan ketara perolehan inventori terhadap kecairan PT Elang Mahkota Teknologi Tbk untuk tempoh 2009-2017. Dan pembolehubah perolehan inventori mempunyai hubungan negatif ke arah kecairan.

2. Tiada perolehan perolehan yang ketara terhadap kecairan PT Elang Mahkota Teknologi Tbk dalam tempoh 2009-2017. Dan pembolehubah perolehan akaun yang diterima mempunyai hubungan negatif terhadap kecairan.

3. Tiada kesan ketara antara perolehan inventori dan perolehan boleh terima bersama dengan kecairan PT Elang Mahkota Teknologi Tbk untuk tempoh 2009-2017. Perolehan inventori dan akaun perolehan belum terima ke arah kecairan menyumbang $34.3 \%$. Perolehan inventori dan perolehan akaun yang belum terima ke arah kecairan mempunyai hubungan yang sederhana, di mana $\mathrm{CR}=13,741-0.783$ Perolehan Inventori-0.789 Perolehan Penerimaan Akaun, yang bermaksud perolehan inventori dan 
perolehan akaun yang diterima mempunyai hubungan negatif ke arah kecairan (nisbah semasa).

\section{B. Saran}

1. Penyelidik seterusnya dijangka menambah pembolehubah lain kerana dalam kajian ini pembolehubah bebas hanya dapat menerangkan pembolehubah bergantung pada $34.3 \%$, manakala baki $65.7 \%$ dipengaruhi oleh faktor lain di luar pembolehubah yang dikaji.

2. Penyelidik seterusnya dijangka menambah sampel penyelidikan dengan menambah objek penyelidikan atau menambah tempoh penyelidikan

\section{DAFTAR PUSTAKA}

Fahmi, Irham. 2011. Analisis Laporan Keuangan. Bandung: Alfabeta.

Ghozali, Imam. 2013. Analisis Multivariate dengan Program SPSS. Semarang: Badan Penerbit Universitas Diponegoro.

Handoko, T. Hani. 2009. Manajemen. Yogyakarta: BPFE.

Harjito, D. Agus, Martono. 2013. Manajemen Keuangan. Yogyakarta: Ekonisia.

Hasibuan, Malayu S.P. 2016. Manajemen Sumber Daya Manusia. Jakarta: Bumi Aksara.

Kasmir. 2015. Analisis Laporan Keuangan. Jakarta: PT Raja Grafindo Persada.

Martani dkk. 2014. Akuntansi Keuangan Menengah Berbasis PSAK. Jakarta: Salemba Empat.

Munawir. 2010. Analisis Laporan Keuangan. Yogyakarta: Liberty.

Riduwan. 2012 Dasar dasar Statistika. Bandung: Alfabeta.

Ristono, Agus. 2009. Manajemen Persediaan. Yogyakarta: Graha Ilmu.

Riyanto, Bambang. 2010. Dasar Dasar Pembelanjaan Perusahaan. Yogyakarta: BPFE

Sartono, Agus. 2010. Manajemen Keuangan Teori dan Aplikasi. Yogyakarta: BPFE.

Solihin, Ismail. 2009. Pengantar Manajemen. Jakarta: Erlangga.

Sugiyono. 2017. Metodologi Penelitian Kuantitatif, Kualitatif, dan R\&D. Bandung: Alfabeta.

Sutrisno. 2012. Manajemen Keuangan Teori, Konsep dan Aplikasi. Yogyakarta: Ekonisia. 